\title{
Penyakit Tuberkulosis di Puskesmas Dosay Sentani Barat Kabupaten Jayapura Tahun 2017-2019
}

\author{
Asrianto $^{1^{*}}$, Fachruddin $^{2}$, Indra Taufik Sahli ${ }^{3}$ \\ 1) Jurusan Teknologi Laboratorium Medis Poltekkes Jayapura, asriantolopa98@ gmail.com \\ ${ }^{2}$ Institut Teknologi dan Kesehatan Avicenna Kendari, fachruddin.ifo@gmail.com \\ 3) Jurusan Teknologi Laboratorium Medis Poltekkes Jayapura, indrataufiksahli@ gmail.com
}

\begin{abstract}
ABSTRAK
Provinsi Papua merupakan salah satu wilayah dengan kasuss TB tertinggi di Indonesia. Khusus di wilayah kerja Puskesmas Dosay tahun 2017 terdapat 34 kasus, 24 kasus di tahun 2018 dan tahun 2019 sebanyak 32 kasus. Penelitian ini bertujuan untuk mengetahui jumlah kasus penyakit TB di Puskesmas Dosay, berdasarkan jenis kelamin, umur, lokasi kejadian anatomi TB dan tempat tinggal. Jenis penelitian adalah deskriptif kuantitatif. Sumber data berupa data rekam medis hasil pemeriksaan TB. Data dianalisis secara statistik deskriptif. Hasil penelitian menunjukkan tahun 2017 dan 2018, penderita TB didominasi perempuan yaitu masing-masing (59,3\%) dan (70,8\%) sedangkan tahun 2019 jumlah laki-laki penderita TB lebih tinggi (61,7\%). Jumlah penderita TB tertinggi tahun 2017 terdapat pada golongan umur 2534 tahun yaitu sebanyak (37,5\%) Sementara, golongan umur 0-14 tahun adalah yang tertinggi pada tahun 2018 dan 2019 yaitu (33,3\%) dan (47\%). Jumlah kasus TB tahun 2017-2019 pasien TP lebih banyak dibandingkan TEP. Kasus TB pada tahun 2017 banyak ditemukan terjadi di Kampung Waibron dan Kampung Maribu yaitu (31,2\%) dan (28,8\%, tahun 2018 Kampung Maribu yang tertinggi, disusul oleh Kampung Waibron yang masing-masing (41,6\%) dan (29,1\%). Adapun tahun 2019, penderita TB terbanyak ditemukan di Kampung Sabron Yaru yakni sebanyak $32,3 \%$. Simpulan pada tahun 2017 dan 2018 penderita TB perempuan lebih banyak, sedangkan tahun 2019 kasus TB tertinggi pada laki-laki. Kasus TB tahun 2017-2019 banyak ditemukan pada golongan umur <15 tahun. Lokasi anatomi yang paling banyak diserang TB adalah paru-paru. Daerah yang kasus TB relatif tinggi adalah Kampung Waibron, Kampung Maribu, dan Kampung Sabron Yaru.
\end{abstract}

Kata Kunci: Jumlah kasus, Tuberkulosis, Dosay

\begin{abstract}
Papua Province is one of the regions with the highest tuberculosis cases in Indonesia. Especially in the Dosay Health Center's working area, in 2017 found 34 cases, 24 cases in 2018, and 32 cases in 2019. This study aimed to determine the number of cases of TB at the Dosay Public Health Center in 2017-2019, based on gender, age, location of TB anatomy, and place of residence. This study is a quantitative descriptive study. The data source was collected from the $\mathrm{Tb}$ case examination's medical record and then analyzed with a descriptive statistic. The results showed that in 2017 and 2018, TB patients tended to be more dominated by women, namely (59.3\%) and (70.8\%), respectively. While in 2019, the number of men with TB was (61.7\%). The highest number of TB sufferers in 2017 was in the age group 25-34 years, namely (37.5\%). Meanwhile, the 0-14-year age group was the highest in 2018 and 2019, namely (33.3\%) and (47\%). The number of pulmonary tuberculosis cases in 2017-2019 was higher than extrapulmonary tuberculosis. TB cases in 2017 were found mostly in Waibron Village and Maribu Village, namely (31.2\%) and (28.8\%). In 2018 Maribu Village had the highest, followed by Waibron Village, respectively (41.6\%) and (29.1\%). As for 2019, the most TB patients were found in Sabron Yaru Village with (32.3\%). In conclusion, in 2017 and 2018, there were more female TB cases. While in 2019, the highest TB cases were in men. TB cases in 2017-2019 are mostly found in the age group <15 years. The anatomical location most commonly attacked by TB is the lungs. The areas with relatively high TB cases were Waibron, Maribu, and Sabron Yaru Village.
\end{abstract}

Keywords: Number of cases, Tuberculosis, Dosay

*Korenpondesi Author: Asrianto, Poltekkes Jayapura, asriantolopa98@gmail.com, +6282187730445 


\section{PENDAHULUAN}

Tuberkulosis (TB) merupakan jenis penyakit infeksi bakterial paling mematikan di dunia, kedua setelah infeksi penyakit Human Immunodeficiency Virus $(H I V))^{1,2}$ Penyakit tuberkulosis ini diperankan oleh bakteri batang Mycobacterium tuberculosis. Umumnya $M$. tuberculosis memengaruhi paru-paru (TB paru atau TP), akan tetapi bakteri ini juga dapat bekerja pada lokasi anatomis lainnya (TB luar paru atau $T E P$ ). TEP dapat menjangkiti organ seperti kelenjar getah bening, pleura, rongga perut, tulang dan sendi, selaput otak, jaringan kutaneus, dan sistem gastrointestinal. ${ }^{3,4,5}$

Penyakit Tuberkulosis yang selanjutnya menggunakan istilah TB dapat menyerang siapa saja dan dimana saja. Insiden TB dipengaruhi oleh beberapa faktor, seperti umur, jenis kelamin, kebiasaan merokok, kepadatan hunian, pekerjaan, status ekonomi, dan pelayanan medis. ${ }^{6,7}$ Sebagian besar orang yang terinfeksi $M$. tuberculosis adalah orang dewasa yang mencapai sekitar $90 \%$ dengan rasio laki-laki : perempuan adalah $2: 1{ }^{8}$

$$
\text { Orang-orang yang terjangkit } M \text {. }
$$
tuberculosis mengembangkan penyakit TB sepanjang hidup mereka. Proporsinya relatif kecil (5-10\%) dari perkiraan 1,7 miliar orang. Faktor risiko infeksi TB lebih rentan terjadi pada orang yang menderita HIV/AIDS; juga pada orang-orang yang dipengaruhi oleh faktor-faktor risiko seperti diabetes, kurang gizi, konsumsi alkohol dan merokok. ${ }^{89}$ Kerentanan terhadap TB merupakan faktor yang ditentukan oleh risiko untuk mendapatkan infeksi dari risiko munculnya penyakit klinis setelah infeksi terjadi. ${ }^{7}$ Penyakit TB sangat rentan terjadi pada orang yang daya tahan tubuhnya lemah. Seorang penderita TB diperkirakan dapat menulari 1 dari 10 orang di sekitarnya atau menularkan 10-15 orang per tahun bagi penderita TB paru BTA $(+) .{ }^{10}$ Penyebaran penyakit TB terjadi melalui tetesan (droplet) yang berada di udara. Droplet yang mengandung $M$. tuberculosis ditransmisikan ke udara saat penderita batuk, bersin atau berbicara. Orang dapat tertular bila droplet tersebut terhirup masuk ke alveoli. ${ }^{6,10,11}$

Tingkat kasus TB di level nasional tiap negara bervariasi, kurang dari 50 hingga 5.000 jiwa per 1 juta populasi per tahun. Tetapi, hampir 90\% kasus, setiap tahun dilaporkan terjadi di 30 negara dengan beban TB tinggi. ${ }^{8}$ Berdasarkan laporan WHO dalam Global Tuberculosis Report tahun 2019, menyebutkan jumlah estimasi kasus TB di Indonesia sebanyak 845.000 kasus, dengan mortalitas 93.000. Angka tersebut meningkat signifikan dari tahun 2017 yang tercatat hanya 567.869 kasus. Prevalensi ini menempatkan Indonesia dalam daftar 30 negara dengan kasus TB tertinggi.

Secara nasional, Provinsi Papua merupakan salah satu wilayah dengan kasus TB paru tertinggi berdasarkan data riset Dinas Kesehatan Provinsi Papua. Pada tahun 2016 terdapat 3.474 kasus TB paru, tahun 2017 ditemukan 3.618 kasus dan terus mengalami peningkatan pada tahun 2018 menjadi sebanyak 4.150 kasus. Khusus di Kabupaten Jayapura, sejak awal 2019 hingga awal 2020 tercatat 1.322 warganya menderita tuberkulosis. Angka ini meningkat drastis dibandingkan tahun 2018 yang hanya 901 kasus. $^{12}$

Berdasarkan hasil wawancara dengan salah seorang petugas kesehatan Puskesmas Dosay di Distrik Sentani Barat, diperoleh informasi bahwa wilayah kerja Puskesmas Distrik Sentani Barat termasuk daerah yang memiliki jumlah kasus TB cukup tinggi. Lebih lanjut responden menjelaskan bahwa hal tersebut dipengaruhi oleh kurangnya tingkat kesadaran dan kepatuhan individu. Hal ini nampak pada sebagian masyarakat cenderung mengabaikan penyakit TB, keengangan masyarakat untuk memeriksakan diri ke Puskesmas, dan penderita kurang disiplin dalam pengobatan. Disamping faktor kesadaran dan kepatuhan individu, faktor lingkungan juga ikut memengaruhi penyebaran M.tuberculosis, hal ini sebagaimana hasil studi analisis spasial menunjukkan bahwa karakteristik suhu udara, 
kelembaban udara, kecepatan angin dan ketinggian wilayah mempengaruhi penyebaran kasus tuberkulosis paru di wilayah kerja Puskesmas Sentani. ${ }^{29}$ secara kumulatif faktorfaktor tersebut meningkatkan risiko penyebaran M.tuberculosis. Penelitian ini bertujuan untuk mengetahui jumlah kasus TB di Distrik Sentani Barat tahun 2017 s/d 2019, berdasarkan jenis kelamin, umur, lokasi kejadian anatomi TB dan tempat tinggal.

\section{METODOLOGI}

Penelitian ini termasuk penelitian deskriptif kuantitatif. Penelitian ini dilaksanakan pada bulan Juli tahun 2020 di Puskesmas Dosay Distrik Sentani Barat Papua. Sumber data penelitian berupa data rekam medis pemeriksaan penyakit TB dari Puskesmas Dosay Distrik Sentani Barat tahun tahun 2017, 2018 dan 2019. Data diolah berdasarkan kategori jenis kelamin, golongan umur, lokasi anatomi TB, dan asal tempat tinggal penderita. Data disajikan dalam bentuk grafik dan tabel. Analisis data dilakukan secara deskriptif.

\section{HASIL DAN PEMBAHASAN}

Tuberkulosis (TB) merupakan penyakit menular yang telah lama mendunia. Bahkan penyakit ini masuk dalam 10 besar penyebab kematian tertinggi di dunia. Prevalensi penyakit TB di Indonesia masih relatif tinggi, hal ini tercatat dalam Global Tuberculosis Report tahun 2019. Secara regional angka kasus TB di Provinsi Papua mengalami peningkatan setiap tahunnya. Angka kasus peningkatan TB dipengaruhi oleh banyak faktor antara lain faktor sosial ekonomi, status gizi, umur, jenis kelamin, penyakit penyerta seperti HIV/AIDS, diabetes melitus, gizi buruk dan lain-lain.

Hasil pemeriksaan TB di Puskesmas Dosay Distrik Sentani Barat berdasarkan jumlah kasus tahun 2017, 2018 dan 2019 disajikan pada tabel 1 berikut.
Tabel 1. Jumlah Kasus Penderita TB di Puskesmas Dosay

\begin{tabular}{lcc}
\hline No & Tahun & Jumlah Kasus \\
\hline 1 & 2017 & 32 \\
2 & 2018 & 24 \\
3 & 2019 & 34 \\
\hline
\end{tabular}

Tabel 1 menunjukkan prevalensi TB berdasarkan pemeriksaan di Puskesmas Dosay terjadi fluktuasi, tahun 2017 kasus yang tercatat 32 orang, kasus 2018 menurun menjadi 24 kasus, kembali meningkat sebanyak 34 kasus pada tahun 2019 .

Tabel 2. Penderita TB Berdasarkan Jenis Kelamin

\begin{tabular}{ccccc}
\hline \multirow{2}{*}{ Tahun } & \multicolumn{4}{c}{ Jenis Kelamin } \\
\cline { 2 - 5 } & \multicolumn{2}{c}{ Laki-laki } & \multicolumn{2}{c}{ Perempuan } \\
\cline { 2 - 5 } & $\mathrm{n}$ & $\%$ & $\mathrm{n}$ & $\%$ \\
\hline 2017 & 13 & 40,6 & 19 & 59,3 \\
2018 & 7 & 29,1 & 17 & 70,8 \\
2019 & 21 & 61,7 & 13 & 38,2 \\
\hline
\end{tabular}

Tabel 2 menunjukkan bahwa pada tahun 2017 dan 2018, penderita TB cenderung lebih didominasi perempuan yaitu masing-masing 19 orang $(59,3 \%)$ dan 17 orang $(70,8 \%)$ dibandingkan laki-laki hanya 13 orang $(40,6 \%)$ dan 7 orang $(29,1 \%)$. Baru pada tahun 2019 jumlah laki-laki penderita TB lebih banyak (21 orang) daripada perempuan (13 orang). Bahkan persentase peningkatannya sangat signifikan dari $29,1 \%$ (7 orang) pada tahun 2018 menjadi $61,7 \%$ (21 orang) pada tahun 2019.

Tahun 2019 jumlah penderita laki-laki lebih banyak dibandingkan perempuan, malahan angkanya menunjukkan adanya peningkatan dibandingkan tahun sebelumnya. Di Negara berkembang, angka kejadian kasus TB paru, lakilaki 2,3 kali lebih berisiko dibandingkan perempuan. ${ }^{13}$ Bahkan Infodatin Kemenkes (2018) mengungkap bahwa mengacu pada Survei Prevalensi TB, prevalensi TB 3 kali lebih tinggi pada laki-laki dibandingkan pada perempuan. Lazimnya, laki-laki lebih rentan terserang penyakit TB disebabkan oleh gaya hidup dan aktivitas. Merokok dan mengonsumsi alkohol 
merupakan gaya hidup yang paling sering dilakoni oleh kaum Adam. Penelitian tentang relasi perokok-pasien penderita TB telah banyak dilaporkan. Terdapat hubungan yang kuat perokok dan infeksi TB. ${ }^{14,15,16}$ Menurut $^{17}$ turut melaporkan bahwa dari 85 penderita TB perokok, 43 orang di antaranya positif berdasarkan pewarnaan BTA. Perilaku merokok dapat menurunkan kekebalan tubuh dan merusak mekanisme mucociliary clearance. ${ }^{18}$ Hal inilah yang memicu mudahnya infeksi $M$. tuberculosis. Selanjutnya prilaku mengkosumsi alkohol juga ikut andil dalam meningkatkan resiko infeksi TB. Hal ini berdasarkan laporan WHO, penyalagunaan alkohol meningkatkan risiko tertular TB tiga kali lipat. ${ }^{19}$ Lebih lanjut kira-kira $10 \%$ kasus TB dunia disebabkan oleh prilaku alkoholisme. ${ }^{20}$

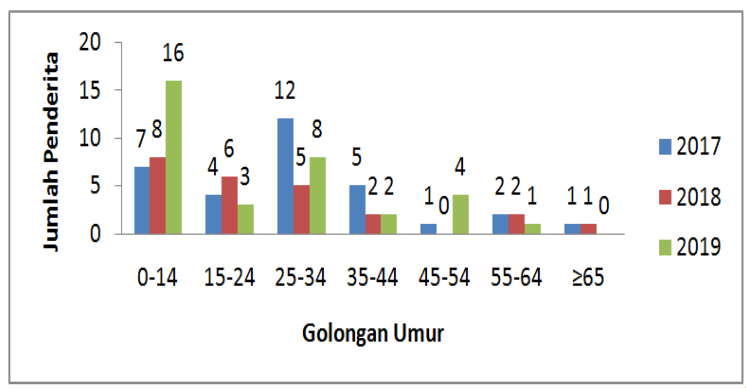

Gambar 1. Penderita TB Berdasarkan Golongan Umur

Gambar 1 menunjukkan jumlah penderita TB berdasarkan kategori kelompok umur pada rentang tahun 2017-2019. Pada tahun 2017, jumlah penderita TB tertinggi terdapat pada golongan umur 25-34 tahun yaitu sebanyak 12 orang $(37,5 \%)$ dan yang terrendah adalah golongan umur 45-54 tahun dan > 65 tahun yaitu masing-masing hanya 1 orang $(3,1 \%)$. Sementara itu, golongan umur 0-14 tahun adalah yang tertinggi pada tahun 2018 dan 2019 yaitu 8 orang $(33,3 \%)$ dan 16 orang $(47 \%)$ secara berturut-turut. Pada tahun yang sama, tidak ditemukan adanya penderita TB pada kelompok usia 45-54 tahun dan $>65$ tahun secara berturut-turut. Secara keseluruhan, kelompok usia 0-14 tahun adalah yang terbanyak jumlah penderita TB dibandingkan kelompok usia lainnya. Bahkan pada kelompok usia tersebut jumlah kasus TB tampak meningkat setiap tahunnya.

Penyakit tuberkulosis dapat menyerang siapa saja dari berbagai golongan umur, mulai dari anak-anak, dewasa dan manula. Berdasarkan data pemeriksaan TB di Puskesmas Dosay, terjadi peningkatan jumlah kasus TB dari tahun 2017 hingga tahun 2019 pada kelompok usia 0-14. Di Negara berkembang, 15\% dari keseluruhan kasus TB terjadi pada anak usia<15 tahun. ${ }^{21}$ Menurut Global Tuberculosis Report (2019), dari perkiraan 10 juta kasus TB tahun 2018 di seluruh dunia, $11 \%$ di antaranya terjadi pada anak-anak. Anakanak, khususnya umur $<5$ tahun merupakan level umur yang sangat rentan akan TB, karena belum memiliki imunitas seluler yang sempurna sehingga meningkatkan progresi infeksi M. tuberculosis. ${ }^{22}$ Kontak penderita TB terhadap anak disinyalir menjadi faktor utama infeksi $M$. tuberculosis. Terjadinya infeksi TB pada anak dikarenakan adanya kontak langsung dengan orang dewasa sakit TB aktif. Mayoritas kasus transmisi penyebaran TB

melalui kontak dalam rumah dan luar rumah dengan penderita TB. Pasien TB dengan BTA positif memberi kemungkinan risiko penularan lebih besar daripada pasien BTA negatif. Hal ini dibuktikan penelitian, bahwa anak memiliki risiko $60-80 \%$ infeksi TB dari pasien BTA positif. ${ }^{21,23}$

Bila rentang umur 15-64 tahun dianggap sebagai dewasa, maka secara keseluruhan kasus TB di Puskesmas Dosay sepanjang tahun 20172019 didominasi kelompok dewasa.Temuan ini sejalan dengan laporan mayoritas pasien TB di Puskesmas Tuminting Manado adalah mereka yang berusia antara 15-64 tahun. Kelompok umur tersebut digolongkan sebagai usia produktif yang mana pada usia tersebut setiap orang cenderung memiliki aktivitas yang terbilang tinggi. Dengan demikian peluang terpajan $M$. tuberculosis lebih besar.Kelompok usia produktif 5-6 kali berisiko terserang penyakit TB. ${ }^{2,24}$ 
Tabel 3. Penderita TB Berdasarkan Lokasi Anatomi

\begin{tabular}{ccccccc}
\hline & \multicolumn{3}{c}{ Klasifikasi Berdasarkan Lokasi Anatomi } \\
\cline { 2 - 6 } Tahun & \multicolumn{2}{c}{ TP } & \multicolumn{3}{c}{ TEP } & \multicolumn{3}{c}{ TP dan TEP } \\
\cline { 2 - 6 } & $\mathrm{n}$ & $\%$ & $\mathrm{n}$ & $\%$ & $\mathrm{n}$ & $\%$ \\
\hline 2017 & 29 & 90,6 & 3 & 9,3 & 0 & 0 \\
2018 & 16 & 66,6 & 8 & 33,3 & 0 & 0 \\
2019 & 18 & 52,9 & 14 & 41,1 & 2 & 5,8 \\
\hline
\end{tabular}

Tabel 3 menunjukkan bahwa dari tahun 2017-2019 penderita TB paru adalah yang terbanyak dibandingkan lokasi anatomi lainnya. Namun demikian, penderita TB ekstra paru memperlihatkan kecenderungan adanya peningkatan jumlah penderita setiap tahunnya. Sementara kasus TB pada lokasi anatomi paru dan ekstra paru baru muncul pada tahun 2019, meskipun jumlahnya relatif sedikit yaitu 2 orang. Kasus tersebut tidak ditemukan pada dua tahun sebelumnya. Jenis TB ekstra paru dapat terjadi pada semua level usia, anak dewasa dan manula. Faktor risiko yang terlibat dalam pengembangan TB ekstra paru terutama adalah usia, jenis kelamin perempuan, infeksi HIV dan adanya penyakit penyerta (komorbid) seperti ginjal kronis, DM dan imunosupresi. ${ }^{25}$

Kuman M. tuberculosis umumnya menyerang paru-paru (TP). Tuberkulosis paru mencakup $80 \%$ kasus TB, namun sekitar 20-25\% kasus TB terjadi diluar paru (TEP), infeksi dapat menyerang dan menyebar ke organ tubuh seperti getah bening (limfa), tulang ataupun usus. ${ }^{26,27}$ Berdasarkan jumlah kasus TB tahun 2017-2019 di Puskesmas Dosay, pasien TP lebih banyak dibandingkan TEP. Hasil ini serupa yang melaporkan bahwa $89,2 \%$ pasien di BBKPM Bandung tahun 2014 merupakan penderita TP. Lebih jauh dijelaskan bahwa penyebaran TEP sangat tergantung pada sistem imunitas seluler. Granuloma yang dibentuk dari sel $\mathrm{T}$ dan makrofag dapat mencegah progesif infeksi bakteri ke organ tubuh lain. ${ }^{4}$

Data penderita TB berdasarkan kategori asal tempat tinggal disajikan pada tabel 4. Kasus TB pada tahun 2017 banyak ditemukan terjadi di Kampung Waibron dan Kampung Maribu yaitu 10 orang $(31,2 \%)$ dan 9 orang $(28,8 \%)$ secara berturut-turut. Tahun 2018 gantian Kampung Maribu yang tertinggi kasus TB, disusul oleh Kampung Waibron yang masing-masing 10 orang $(41,6 \%)$ dan 7 orang $(29,1 \%)$. Adapun tahun 2019, penderita TB terbanyak ditemukan di Kampung Sabron Yaru yakni sebanyak 11 kasus (32,3\%). Di kampung tersebut juga memperlihatkan adanya peningkatan jumlah penderita TB hampir 5 kali lipat, walaupun pada tahun 2018 sempat terjadi penurunan dari 5 orang menjadi 2 orang.

Tabel 4. Penderita TB Berdasarkan

Tempat Tinggal

\begin{tabular}{|c|c|c|c|c|c|c|c|c|c|c|c|c|}
\hline \multirow{3}{*}{ Tahun } & \multicolumn{12}{|c|}{ Tempat Tinggal } \\
\hline & \multicolumn{2}{|c|}{ Maribu } & \multicolumn{2}{|c|}{ Waibron } & \multicolumn{2}{|c|}{ Dosay } & \multicolumn{2}{|c|}{ Sabron Yaru } & \multicolumn{2}{|c|}{ Sabron Sari } & \multicolumn{2}{|c|}{ Kampung lain } \\
\hline & $\mathrm{n}$ & $\%$ & $\mathrm{n}$ & $\%$ & $\mathrm{n}$ & $\%$ & $\mathrm{n}$ & $\%$ & $\mathrm{n}$ & $\%$ & $\mathrm{n}$ & $\%$ \\
\hline 2017 & 9 & 28,8 & 10 & 31,2 & 6 & 18,75 & 5 & 15,6 & 1 & 3,1 & 1 & 3,1 \\
\hline 2018 & 10 & 41,6 & 7 & 29,1 & 3 & 12,5 & 2 & 8,3 & 2 & 8,3 & 0 & 0 \\
\hline 2019 & 6 & 17,6 & 7 & 20,5 & 6 & 17,6 & 11 & 32,3 & 2 & 5,8 & 2 & 5,8 \\
\hline
\end{tabular}

Lingkungan sangat berkaitan erat dengan infeksi dan penyebaran penyakit TB. Daerah di Distrik Sentani Barat dengan pasien TB terbanyak berdasarkan data dari Puskesmas Dosay tahun 2017 dan 2018 adalah Kampung Waibron dan Kampung Maribu. Sementara tahun 2019 kasus terbanyak dan cenderung meningkat ditemukan di Kampung Sabron Yaru. Hasil penelitian menunjukkan bahwa karakteristik suhu udara, kelembaban udara, kecepatan angin dan ketinggian wilayah daerah Sentani sangat memerngaruhi penyebaran kasus tuberkulosis paru. ${ }^{28}$ Daerah yang tinggi kasus TB patut diduga dipengaruhi oleh kondisi tempat tinggal dan perilaku masyarakatnya. Faktor risiko lingkungan fisik rumah yang mencakup ventilasi, kepadatan 
hunian, intensitas pencahayaan, suhu dan kelembaban ruangan berkorelasi positif dengan jumlah kasus TB. ${ }^{10,30}$, Lebih lanjut, laporan penelitian menyatakan bahwa faktor risiko perilaku yang meliputi kebiasaan membuang dahak pada lingkungan terbuka dan kebiasaan batuk atau bersin dengan tanpa menutup mulut turut bertanggung jawab dalam kejadian penyakit TB. ${ }^{10}$ Selain itu, pasien kasus TB di suatu daerah dengan kondisi lingkungan bermasalah sangat berpeluang dapat menularkan kepada anggota masyarakat lain. Bakteri M.tuberculosis akan menetap di udara selama kurang lebih 2 jam sehingga memiliki kemungkinan untuk menularkan penyakit pada anggota masyarakat yang belum terpapar bakteri M. tuberculosis. ${ }^{28}$

\section{SIMPULAN DAN SARAN}

Angka kasus tuberkulosis di Puskesmas Dosay Distrik Sentani Barat, Provinsi Papua. Pada tahun 2017 dan 2018 penderita TB perempuan lebih banyak, sedangkan tahun 2019 kasus TB tertinggi pada laki-laki. Kasus TB pada tahun 2017, 2018 dan 2019 banyak ditemukan pada golongan umur $<15$ tahun. Lokasi anatomi yang paling banyak diserang TB adalah paru-paru. Daerah yang kasus TB relatif tinggi adalah Kampung Waibron, Kampung Maribu, dan Kampung Sabron Yaru.

Sebaiknya dilakukan penelitian lanjutan tentang faktor-faktor risiko yang menyebabkan kasus penyakit TB.

\section{UCAPAN TERIMAH KASIH}

Kami mengucapkan terimah kasih kepada Unit Pusat Penelitian dan Pengabdian Masyarakat Poltekkes Jayapura, pimpinan dan staf Puskesmas Dosay dan seluruh pihak-pihak yang membantu dalam penelitian dan publikasi.

\section{REFERENSI}

1. Wijaya I. Tuberkulosis paru pada penderita diabetes melitus. CDK-229. 2015; 42 (6): 412-417. Tersedia di : http://www.scribd.com
2. Laily DW, Rombot DV dan Lampus BS. Karakteristik pasien tuberkulosis paru di Puskesmas Tuminting Manado. Jurnal Kedokteran Komunitas dan Tropik. 2015; 3 (1): 1-5.

3. Elliot $\mathrm{T}$, Worhington $\mathrm{T}$, Osman $\mathrm{H}$ dan Gill M. Mikrobiologi kedokterandan infeksi. Penerbit Buku Kedokteran EGC. Jakarta; 2009

4. Azizi FH, Husin UA dan Rusmartini $T$. Gambaran karakteristik tuberkulosis paru dan ekstra paru di BBKPM Bandung 2014. Prosiding Pendidikan Dokter. 2014; 860-866.

5. Sunnetcioglu A, Sunnetcioglu M, Binci I, Baran AI, Karahocagil MK and Saydan MR.Comparative analysis of pulmonary and extrapulmonary tuberculosis of 411 cases. Annals of Clinical Microbiology and Antimicrobials. 2015;14 (34): 1-5.

6. Sejati A dan Sofiana L. Faktor-faktor terjadinya tuberkulosis. KEMAS.2015; 10 (2): 122-128.

7. Brooks GF, Carrol KC, Butel JS, Morse SA dan Mietzner TA. Jawetz, Melnick \& Adelberg Mikrobiologi Kedokteran. Edisi25. Buku Kedokteran EGC. Jakarta; 2010.

8. WHO [homepage on the internet]. Global Tuberculosis Report tersedia di http://www.who.int/tb.

9. Alodokter.com [halaman internet]. Waspadai TBC Kelenjar yang Ditandai dengan Benjolan di Leher. [sitasi 25 Juni 2020], tersedia di https://www.alodokter.com.

10. Wulandari AA, Nurjazuli, dan Adi MS. Faktor risiko dan potensi penularan tuberkulosis paru di Kabupaten Kendal, Jawa Tengah. Jurnal Kesehatan Lingkungan Indonesia.2015; 14 (1): 7-13.

11. Locke T, Keat S, Walker A and Mackinnon. Microbiology and Infectious Disease on The Move. PT Indeks. Jakarta; 2013.

12. IndonesiaInside.id [halaman internet]. Meningkat, Kasus Tuberkulosis Masih Menjadi Momok Kesehatan di Jayapura. 
[sitasi 9 Juli 2020], tersedia di https://indonesiainside.id/news/nusantara/202 0/02/14/meningkat-kasus-tuberkulosis-masihmenjadi-momok-kesehatan-di-jayapura.

13. WHO [homepage on internet]. Global Tuberculosis Control. [citation 11 Juli 2020]. Tersedia

https://apps.who.int/iris/bitstream/handle/106 65/44425/9789241564069_eng.pdf.;jsessioni $\mathrm{d}=$ AE8B4894C79D5842E87B3A10F73D9B1 8 ? sequence $=1$

14. Hapsari AR, Faridah F, Balwa AF, dan Saraswati LD. Analisis kaitan riwayat merokok terhadap pasien tuberkulosis paru (TB paru) di Puskesmas Srondol. Jurnal Ilmiah Mahasiswa. 2013; 3(2).

15. Alavi RN, Shariffi BM and Metanat $M$. Association between tuberculosis and smoking. Int $\mathrm{J}$ High Risk Behav Addict. 2012;1 (2).

16. Tocque K, Bellis MA, Beeching NJ, Syed Q, Remmngton T, Davies PD. A case control study of live style risk factor associated with tuberculosis in Liverpool. Eur Respir J. 2001; 18 (6).

17. Brahmadhi A dan Annisa Y. Perbandingan Antara penderita tuberkulosis perokok dan bukan perokok berdasarkan Basil Tahan Asam (BTA) di RSUD Banyumas. Mediasains. 2016;14(3).

18. Tirtana BT, Muscrichan. Faktor-faktor yang mempengaruhi keberhasilan pengobatan pada pasien tuberkulosis diwilayah jawa Tengah [Disertasi]. Semarang Universitas Diponegoro; 2010.

19. Editorial staff [homepage on internet]. Alcohol and Tuberculosis. [update pada 10 juli 2020]. Tersedia di http://www.alcohol.org/effects/tuberculosis.

20. Rehm J, Samokhvalov AV, Neuman MG, Room R, Parry C, Lonnroth K, Patra J, Poznyak V and Popova S. The association between alcohol use, alcohol use disolder and tuberculosis. BMC Public Health. 2009; 9 : 450.

21. Kartasasmita CB. Epidemiologi Tuberkulosis. Sari Pediatri .2009; 11 (2): 124-129.

22. Narasimhan P, Wood J, MacIntyre CR and Mathai D. Risk factors for tuberculosis [Review Article].Pulmonary Medicine. 2013.

23. Sinfield R, Nyirenda M, haves S, Moly M, Graham M. Risk factors for TB infection and disease in young childhood contacts in Malawi. Ann Trop Paediarr. 2006; 26.

24. Andayani S dan Astuti Y. Prediksi prevalensi kejadian penyakit tuberkulosis paru di Kabupaten Ponorogo Tahun 2016-2020 Berdasarkan Usia. Indones. J. Heal. Sci. 2017;1 (2): 29-33.

25. Lapausa MR, Saldana AM, Asensio AN. 2015. Extrapulmonary tuberculosis : an overview. Rev Esp Sanid Penid.17 :3-11

26. 26Aini N, Ramdhani dan Hatta R. Sistem Pakar pendiagnosis penyakit Tuberkulosis. Jurnal Informatika Mulawarman. 2017; 12 (1).

27. WHO. Global Tuberculosis Control: Epidemiologi, Strategy, Financing. Genewa; 2009.

28. Ayomi AC, Setiani O, Joko T. 2012. Faktor risiko lingkungan fisik rumah dan karakteristik wilayah sebagai determinan kejadian penyakit tuberkulosis paru di Wilayah Kerja Puskesmas Sentani Kabupaten Jayapura Provinsi Papua. Jurnal Kesehatan Lingkungan Indonesia.. 11 (1) : 1-8.

29. Budi IS, Ardillah Y, Sari IP, dan Septiawati D. Analisis Faktor Risiko Terjadinya Penyakit Tuberkulosis bagi Masyarakat Daerah Kumuh Kota Palembang.JKLI. 2018;17 (2): 87-94.

30. Kemenkes RI. Pedoman Nasional Penanggulangan Tuberkulosis. Dirjen P2M\&PL. Jakarta; 2014. 